\title{
Ophiocordyceps aphrophoridarum sp. nov., a new entomopathogenic species from Guizhou, China
}

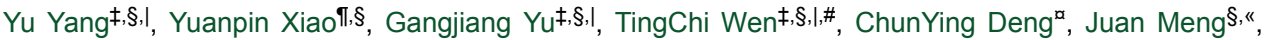 \\ Zhenghua $\mathrm{Lu}^{\ddagger}, \S$, \\ ‡ School of liquor and food engineering, Guizhou University, Guiyang, China \\ $\S$ The Engineering Research Center of Southwest Bio-Pharmaceutical Resources, Ministry of Education, Guizhou University, \\ Guiyang, China \\ | Mushroom Research Center, School of agriculture, Guizhou University, Guiyang, China \\ IT Mae Fah Luang University, Chiang Rai, Thailand \\ \# State Key Laboratory Breeding Base of Green Pesticide and Agricultural Bioengineering, Key Laboratory of Green Pesticide \\ and Agricultural Bioengineering, Ministry of Education, Guizhou University, Guiyang, China \\ a Guizhou Institute of Biology, Guizhou Academy of Sciences, Guiyang, China \\ « Mushroom Research Center, School of agriculture, Guiyang, China
}

Corresponding author: TingChi Wen (tingchiwen@yahoo.com)

Academic editor: Danny Haelewaters

Received: 18 Mar 2021 | Accepted: 02 Sep 2021| Published: 22 Dec 2021

Citation: Yang Y, Xiao Y, Yu G, Wen T, Deng C, Meng J, Lu Z (2021) Ophiocordyceps aphrophoridarum sp. nov., a new entomopathogenic species from Guizhou, China. Biodiversity Data Journal 9: e66115.

https://doi.org/10.3897/BDJ.9.e66115

\section{Abstract}

\section{Background}

Ophiocordyceps is the largest genus in the family Ophiocordicipitaceae, including many entomopathogenic species. In recent years, many species have been described in this genus, with a wide range of host insects. Entomopathogenic fungi include ecologically, economically and medicinally important species, but a large portion of their diversity remains to be discovered and described.

\section{New information}

In this study, a new species, Ophiocordyceps aphrophoridarum sp. nov, parasitising Aphrophoridae sp. (Hemiptera) is proposed from China, based on evidence from 
morphology and molecular phylogenetic analyses. This species is characterised by fibrous, pigmented stromata, cylindrical asci and filiform ascospores. Compared to its closest relative, $O$. tricentri, the new species has wider perithecia and longer asci. Molecular phylogenetic analyses of a multilocus dataset (consisting of SSU, ITS, LSU, TEF1, RPB1 and RPB2) confirm its placement in Ophiocordyceps. Ophiocordyceps aphrophoridarum is morphologically described and illustrated with colour photographs. Morphological comparisons with closely-related species are also presented in tabulated format.

\section{Keywords}

one new taxon, morphology, Ophiocordyceps, multilocus phylogeny, taxonomy

\section{Introduction}

Insect-associated fungi represent a largely unknown and undescribed group; only $1.5 \%$ of these fungi have been reported (Mueller and Schmit 2007). In 2019, scientists determined 48 new species of animal-associated Sordariomycetes, including eight species of Ophiocordyceps, one of the best-known entomopathogenic genera (Cheek et al. 2020). The following year, 12 new species of Ophiocordyceps were described (Araujo et al. 2020, Tasanathai et al. 2020).

The genus Ophiocordyceps was proposed by Petch 1931) and was originally considered as a subgenus of Cordyceps (Kobayasi 1941, Kobayasi and Shimizu 1983). Sung et al. (2007b) established Ophiocordycipitaceae as a new family in Hypocreales with Ophiocordyceps as type genus. Due to the polyphyletic nature of Cordyceps, species formerly assigned to this genus had to be recombined in Ophiocordyceps (Sung et al. 2007a, Johnson et al. 2009). To date, Ophiocordyceps is the most speciose genus in Ophiocordycipitaceae with 289 accepted species (Index Fungorum, accessed 11 March 2021). Species of Ophiocordyceps are characterised by producing fibrous, hard, flexible, pigmented stromata and cylindrical asci with apical caps (Sung et al. 2007a, Ban et al. 2015, Maharachchikumbura et al. 2015, Wijayawardene et al. 2017, Xiao et al. 2019). The asexual morph of Ophiocordyceps is linked to Hirsutella, Hymenostilbe, Paraisaria, Stibella and Syngliocladium (Sung et al. 2007a, Thanakitpipattana et al. 2020) and known as Hirsutella-like and Hymenostilbe-like (Kepler et al. 2013, Maharachchikumbura et al. 2016, Maharachchikumbura et al. 2015).

Species in Ophiocordycipitaceae are found on a wide range of insect hosts; some taxa are host specific, such as Ophiocordyceps unilateralis sensu lato (De Bekker et al. 2014, Kobmoo et al. 2019). Blattaria, Coleoptera, Dermaptera, Diptera, Hemiptera, Hymenoptera, Isoptera, Lepidoptera, Megaloptera, Neuroptera, Odonata and Orthoptera are the insect orders most commonly reported to be associated with Ophiocordyceps (Evans et al. 2011, Luangsa-Ard et al. 2018, Araujo and Hughes 2019). The functional morphology of Ophiocordyceps is diverse and considered to be exclusively related to the host's ecology and biology (Evans et al. 2011). 
Ophiocordyceps has a pan-global distribution, but is most species-rich in the tropics and subtropics (Petch 1933, Petch 1937, Kobayasi 1941, Tzean et al. 1997, Ban et al. 2015). The Yuntai Mountain Nature Reserve, China, a dolomite karst landform, has become a hotspot for fungal diversity (Luo et al. 2013, Wen et al. 2015, Wen et al. 2017) and, in 2019, samples of Ophiocordyceps were collected that proved to be an undescribed species. Here, we formally describe this species, based on morphological study and the phylogenetic analysis of a multilocus dataset.

\section{Materials and methods}

\section{Collection and morphological characteristics examination}

Two fresh samples of Ophiocordyceps, parasitising Aphrophoridae sp. (Hemiptera), were collected in June 2019 from the broad-leaved forest in Yuntai Mountain Nature Reserve, Guizhou Province, China. The samples were dried with silica gel and then stored in plastic boxes in the Herbarium of Mae Fah Luang University (MFLU). For micro-morphological observations, ascomata were examined using a Motic SMZ 168 Series stereomicroscope (Motic, Xiamen, China). Structures were observed and measured after being sliced with a double-sided blade and placed into water. Microphotographs were taken using an Eclipe 80i compound microscope (Nikon, Tokyo, Japan), fitted with an EOS 600D camera (Canon, Tokyo, Japan). Measurements were made using the Tarosoft (R) Image Frame software $v$. 0.9.7.

\section{DNA extraction, PCR amplification and determination of DNA sequences}

DNA was extracted from dried fruiting bodies using the Fungal gDNA Kit (Biomiga, Sang Diego, CA, USA). We amplified the small and large subunits (SSU, LSU) of the ribosomal RNA gene, internal transcribed spacer region (ITS), translation elongation factor-1a (TEF1) and the largest and second-largest subunit of RNA polymerase II gene (RPB1, RPB2). The following primer pairs were used: NS1/NS4 for SSU, ITS4/ITS5 for ITS, LR0R/LR5 for LSU (Hopple and Vilgalys 1994, Vilgalys and Hester 1990, White et al. 1990), EF1-983F/ EF1-2218R for TEF1 (Sung et al. 2007b), CRPB1A/RPB1Cr for RPB1 and fRPB2-6f/ RPB2-7CR for RPB2 (Castlebury et al. 2004). The 25- $\mu$ PCR reaction volume contained 2 $\mu$ of DNA template, $8.5 \mu$ l of $\mathrm{H}_{2} \mathrm{O}, 1 \mu \mathrm{l}$ of each forward reverse primer and $12.5 \mu \mathrm{l}$ of $2 \times$ benchtoptm Taq Master Mix (Biomiga, San Diego, CA, USA). Cycling conditions were as follows: for SSU and LSU: initial denaturation at $94^{\circ} \mathrm{C}$ for $3 \mathrm{~min}$; followed by 33 cycles at $94^{\circ} \mathrm{C}$ for $30 \mathrm{~s}, 51^{\circ} \mathrm{C}$ for $30 \mathrm{~s}$ and $72^{\circ} \mathrm{C}$ for $2 \mathrm{~min}$; and final extension at $72^{\circ} \mathrm{C}$ for $10 \mathrm{~min}$. For ITS: initial denaturation at $94^{\circ} \mathrm{C}$ for $3 \mathrm{~min}$; followed by 33 cycles of $94^{\circ} \mathrm{C}$ for $30 \mathrm{~s}, 51^{\circ} \mathrm{C}$ for $50 \mathrm{~s}$ and $72^{\circ} \mathrm{C}$ for $45 \mathrm{~s}$; and final extension at $72^{\circ} \mathrm{C}$ for $10 \mathrm{~min}$. For TEF1: initial denaturation at $94^{\circ} \mathrm{C}$ for $3 \mathrm{~min}$; followed by 33 cycles of $94^{\circ} \mathrm{C}$ for $30 \mathrm{~s}, 58^{\circ} \mathrm{C}$ for $50 \mathrm{~s}$ and $72^{\circ} \mathrm{C}$ for $1 \mathrm{~min}$; and final extension at $72^{\circ} \mathrm{C}$ for $10 \mathrm{~min}$. For RPB1: initial denaturation at $94^{\circ} \mathrm{C}$ for $3 \mathrm{~min}$; followed by 33 cycles of $94^{\circ} \mathrm{C}$ for $1 \mathrm{~min}, 52^{\circ} \mathrm{C}$ for $1 \mathrm{~min}$ and $72^{\circ} \mathrm{C}$ for $1 \mathrm{~min}$; and final extension at $72^{\circ} \mathrm{C}$ for $10 \mathrm{~min}$. Lastly, for RPB2: initial denaturation at $94^{\circ} \mathrm{C}$ for 3 min; followed by 33 cycles of $94^{\circ} \mathrm{C}$ for $30 \mathrm{~s}, 54^{\circ} \mathrm{C}$ for $40 \mathrm{~s}$ and $72^{\circ} \mathrm{C}$ for $80 \mathrm{~s}$; and final extension at $72^{\circ} \mathrm{C}$ for $10 \mathrm{~min}$. Amplified PCR products were verified by $1 \%$ agarose gel 
electrophoresis, stained with ethidium bromide in 1× TBE. The PCR products were sequenced by Shanghai Shenggong Biological Engineering Co. (Hangzhou, Shanghai, China). Forward and reverse sequence reads were assembled and edited by BioEdit v. 7.0.9 (Hall et al. 2011).

\section{Sequence alignment and phylogenetic analyses}

Reference sequences (Suppl. materials 1,2) were downloaded from NCBI GenBank, based on previous studies (Suppl. material 2, Ban et al. 2015, Crous et al. 2018, Kepler et al. 2012, Long et al. 2021, Sanjuan et al. 2015, Sung et al. 2007a, Xiao et al. 2019, Araujo et al. 2015, Araujo et al. 2018). Sequences were aligned with MAFFT v.7 (Katoh and Standley 2013, http://mafft.cbrc.jp/alignment/server/). TrimAl v.1.3 (Capella-Gutiérrez et al. 2009) was used for automated alignment trimming for poorly-aligned regions of each locus. Tolypocladium inflation and T. ophioglosoides (Kepler et al. 2012, Schoch et al. 2012) were selected as outgroup taxa.

Maximum Likelihood (ML) analyses were performed using IQ-TREE 2 (Minh et al. 2020) under partitioned models; the built-in ModelFinder (Kalyaanamoorthy et al. 2017) was used to select appropriate models for each of the six loci. Branch support was estimated using 1000 ultrafast bootstrap (UFBoot2) replicates (Hoang et al. 2018). Bayesian Inference (BI) was determined by Markov Chain Monte Carlo (MCMC) sampling using MrBayes v.3.1.2 (Ronquist et al. 2012). The six loci were concatenated into a single dataset. BI was performed with six independent MCMC runs and trees were sampled every $100^{\text {th }}$ generation. The analyses were stopped after 5,000,000 generations when the average standard deviation of split frequencies was below 0.01 . The convergence of the runs was checked using Tracer v.1.6 (Rambaut et al. 2018). The first $25 \%$ of the resulting trees were discarded as burn-in and posterior probabilities (PP) were calculated from the remaining sampled trees. The ML tree was visualised with FigTree v.1.4.0 (http://tree.bio.ed.ac.uk/ software/figtree/).

\section{Taxon treatment}

\section{Ophiocordyceps aphrophoridarum Y.Yang, Y.P. Xiao \& T.C. Wen, sp. nov.}

- IndexFungorum IF558176

\section{Materials}

Holotype:

a. scientificName: Ophiocordyceps aphrophoridarum; country: China; stateProvince: Guizhou; locality: Qiandongnan, Shibing, Yuntaishan; verbatimElevation: 854m; locationRemarks: label transliteration: "Guizhou, Qiandongnan, Shibing, Yuntaishan, on Aphrophoridae sp., 19 June 2019, Yu Yang; verbatimCoordinates: 2706'28.28"N, $108^{\circ} 06^{\prime} 32.15^{\prime \prime} \mathrm{E}$; decimalLatitude: 27.107858; decimalLongitude: 108.108932; georeferenceProtocol: label; lifeStage: Telemorph; catalogNumber: MFLU 20-0641; recordedBy: Yu Yang; identifiedBy: Yuan-pin Xiao; dateldentified: 2020 
Paratype:

a. ScientificName: Ophiocordyceps aphrophoridarum; country: China; stateProvince: Guizhou; locality: Qiandongnan, Shibing, Yuntaishan; verbatimElevation: 859m; locationRemarks: label transliteration: "Guizhou, Qiandongnan, Shibing, Yuntaishan, on Aphrophoridae sp., 19 June 2019, Yu Yang; verbatimCoordinates: $27^{\circ} 06^{\prime} 30.44^{\prime \prime} \mathrm{N}$, $108^{\circ} 06^{\prime 2} 27.15^{\prime \prime}$; decimalLatitude: 27.108457; decimalLongitude: 108.107542; georeferenceProtocol: label; lifeStage: Telemorph; catalogNumber: MFLU 20-0642; recordedBy: Yu Yang; identifiedBy: Yuan-pin Xiao; dateldentified: 2020

\section{Description}

Facesoffungi number: FoF09653

Sexual morph: Stromata $8-10 \mathrm{~cm}$ long, $0.5-3 \mathrm{~mm}$ diam., solitary, yellow, fibrous, unbranched, stipitate, slender. Stipe $7-8 \mathrm{~cm}$ long, $0.1-0.8 \mathrm{~mm}$ diam., cylindrical, with a fertile apex, yellow. Fertile head $1-2 \mathrm{~cm}$ long, $2-5 \mathrm{~mm}$ diam., cylindrical to fusiform, differs from the stipe, yellow, single. Perithecia 638-798 $\times 108-178 \mu \mathrm{m}(=718 \times 143$ $\mu \mathrm{m}, \mathrm{n}=40$ ), obliquely immersed, flask-shaped to elongated obpyriform. Peridium 26$68 \mu \mathrm{m}(=47 \mu \mathrm{m}, \mathrm{n}=50)$ divided into two layers, hyaline, outer layer textura prismatica, inner layer textura porrecta. Asci 337-445 × 6.1-8.7 $\mu \mathrm{m}(=391 \times 7.4 \mu \mathrm{m}, \mathrm{n}=60)$, 8spored, hyaline, filiform, with a thick apex. Apical cap 5.1-8.2 $\times 3.6-5.2 \mu \mathrm{m}(=6.7 \times$ $4.4 \mu \mathrm{m}, \mathrm{n}=40$ ), thick, with a small channel in the centre. Ascospores $258-315 \times 3.1-$ $5.5 \mu \mathrm{m}(=286.5 \times 4.3 \mu \mathrm{m}, \mathrm{n}=50)$, filiform, hyaline, multiseptate, easily breaking into secondary ascospores. Partspore 6.4-8.8 × 1.4-2.4 $\mu \mathrm{m}(=7.6 \times 1.9 \mu \mathrm{m}, \mathrm{n}=90)$, fusoid, 1-celled, hyaline, smooth-walled. Asexual morph: Undetermined (Fig. 1)

\section{Etymology}

Referring to the host, Aphrophoridae sp.

\section{Distribution}

Thus far only known from China.

\section{Host}

Aphrophoridae sp. (Hemiptera), collected from the underside of leaves litter, stromata growing from the prothorax.

\section{Analysis}

\section{Phylogenetic analyses}

A total of 185 sequences, representing 128 species of Ophiocordycipitaceae, were downloaded from GenBank. The final alignment length was 4412 characters, representing 185 taxa (822 for LSU, 481 for ITS, 919 for SSU, 918 for TEF1, 536 for RPB1 and 736 for RPB2) (Suppl. materials 1, 2). Tree topology of the IQ-TREE analysis was similar to the 
one from the Bayesian analyses. The best-scoring $M L(-\operatorname{InL}=81595.8951)$ is shown in Fig. 2.

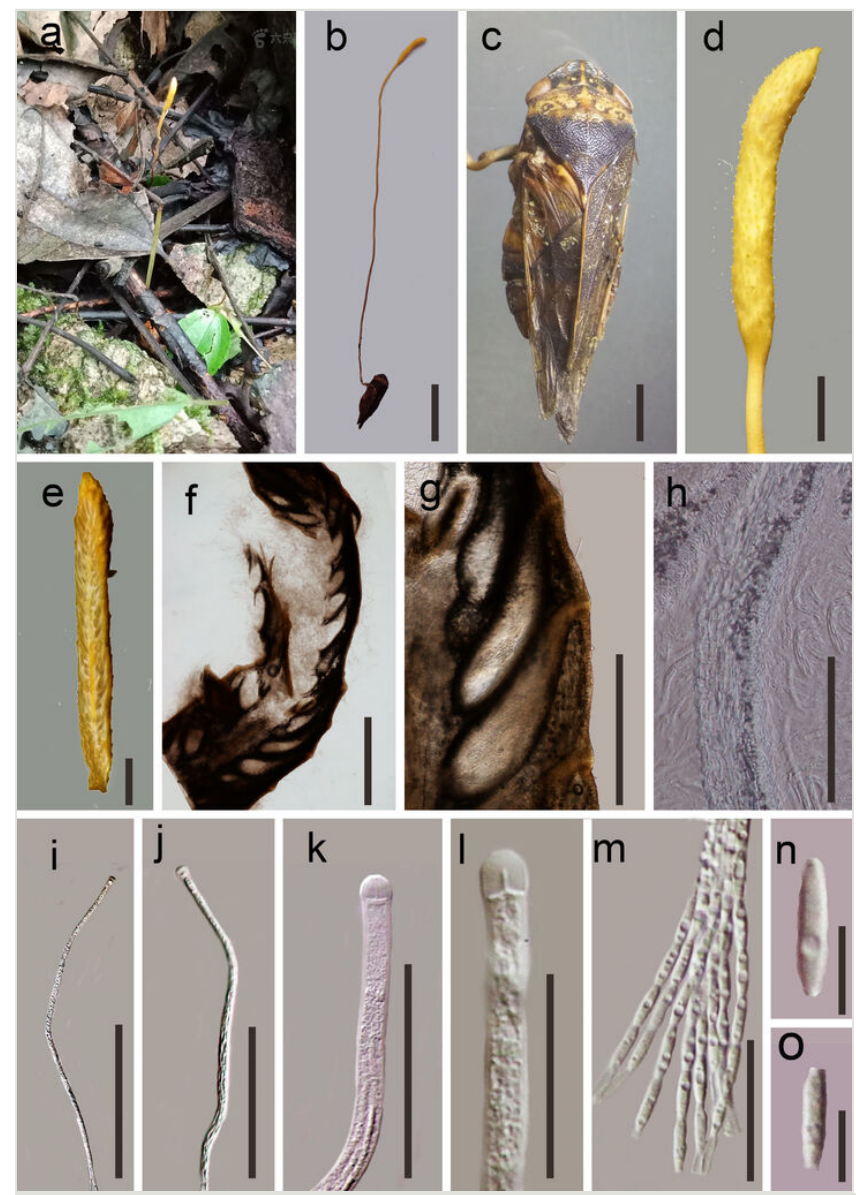

Figure 1. doi

Ophiocordyceps aphrophoridarum (MFLU 20-0641, holotype): a Habitat b Overview of the host and stromata $\mathbf{c}$ Host $\mathbf{d}$ Stromata e Vertical section of the stroma $\mathbf{f}-\mathbf{g}$ Section of ascomata $\mathbf{h}$ Peridium $\mathbf{i}-\mathbf{j}$ Immature to mature asci $\mathbf{k}-\mathbf{I}$ Apical cap of asci $\mathbf{m}$ Part of ascospores $\mathbf{n}-\mathbf{o}$ Partspore. Scale bars: $b=10 \mathrm{~mm}, \mathrm{c}-\mathrm{d}=5 \mathrm{~mm}, \mathrm{e}-\mathrm{f}=1000 \mu \mathrm{m}, \mathrm{g}=500 \mu \mathrm{m}, \mathrm{i}=200 \mu \mathrm{m}, \mathrm{j}=$ $100 \mu \mathrm{m}, \mathrm{k}-\mathrm{m}=30 \mu \mathrm{m}, \mathrm{n}-\mathrm{o}=5 \mu \mathrm{m}$.

\section{Discussion}

The Yuntai Mountain Nature Reserve, situated in Shibing County, Guizhou Province, China, is a dolomite karst landform. The Reserve is home to 106 species of macrofungi (Luo et al. 2013), including two species of Metacordyceps that are currently only known from the holotype locality (Wen et al. 2015, Wen et al. 2017) Here, we present a new entomopathogenic species, $O$. aphrophoridarum, from the same Reserve. 


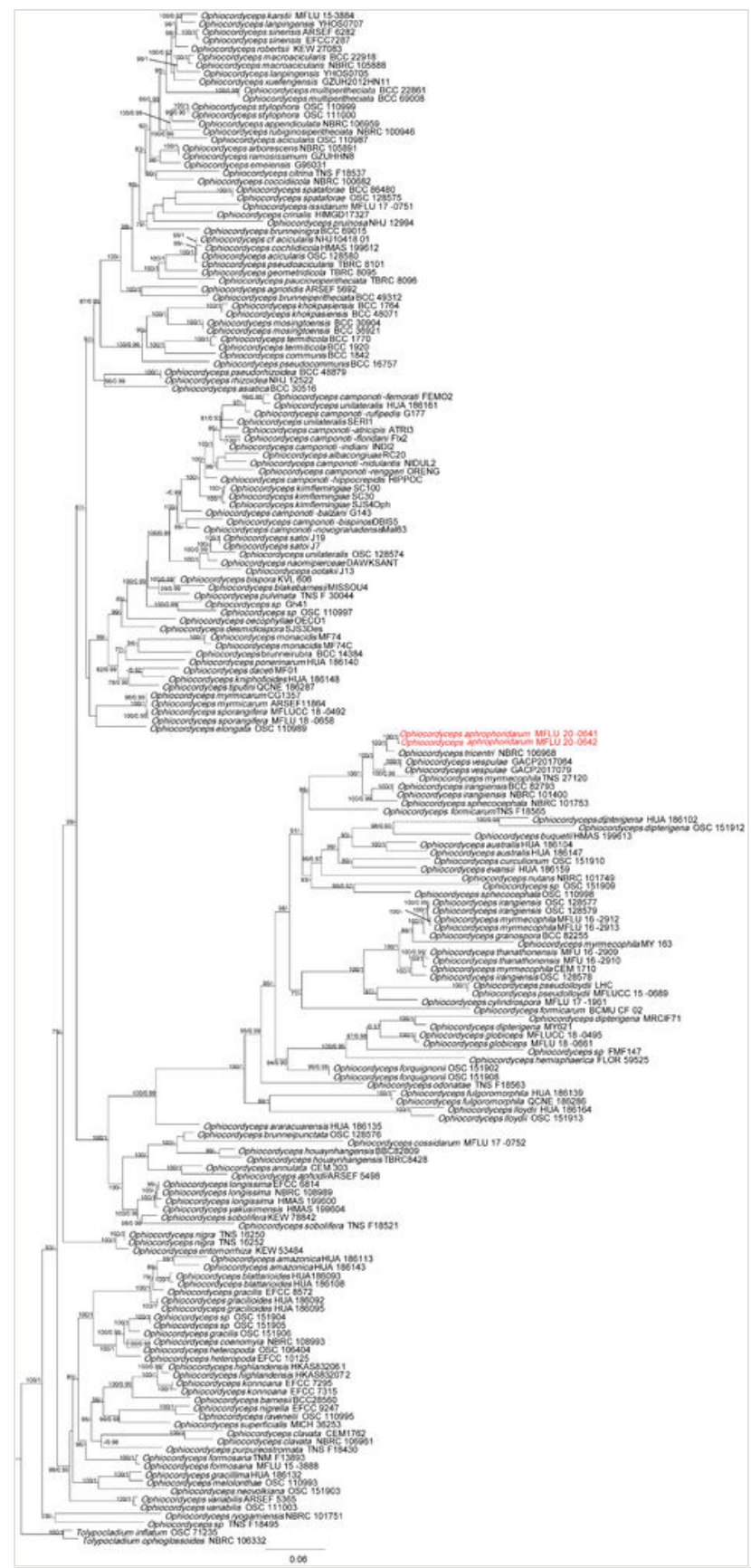

Figure 2. doi

Phylogeny of Ophiocordyceps reconstructed from a six-locus dataset (ITS, SSU, LSU, TEF1, RPB2 and RPB1). The topology is the result of ML inference performed in IQ-TREE. The tree is rooted with both Tolypocladium inflatum and T. ophioglossoides. MLBS $\geq 75$ and BIPP $\geq$ 0.90 are presented above branches. The new species is highlighted in red. 
Ophiocordyceps aphrophoridarum was phylogenetically retrieved as a sister species of $O$. tricentri, in a maximum supported clade with 0 . irangiensis, O. myrmecophila, 0 . sphecocephala and $O$. vespulae (Fig. 2). The sequences of six loci of $O$. tricentri, $O$. irangiensis, O. sphecocephala and $O$. vespulae share between $86-94 \%$ identity with $O$. aphrophoridarum in their ITS, 94-99\% in SSU), 99-100\% in LSU, 97-99\% in TEF1, 9495\% in RPB1 and $95-97 \%$ in RPB2.

Both $O$. irangiensis and $O$. myrmecophila have Formicinae spp. (Hymenoptera) as host (Hywel-Jones 1996), whereas the host of O. aphrophoridarum is Aphrophoridae sp. (Hemiptera). Morphologically, O. aphrophoridarum differs from O. irangiensis in its smaller ascomata, shorter asci and shorter partspores (Hywel-Jones 1996). Ophiocordyceps aphrophoridarum differs from 0 . myrmecophila in terms of having smaller ascomata, shorter asci and longer partspores (Hywel-Jones 1996). The host of O. sphecocephala is Vespula sp. (Hymenoptera) (Hywel-Jones 1995). This species produces larger ascomata, longer asci and longer partspores compared to O. aphrophoridarum (Shrestha and Sung 2005). Additionally, O. vespulae has Vespula sp. as host (Hymenoptera) and is distinct from the new species by its longer asci and partspores (Long et al. 2021).

Ophiocordyceps tricentri is phylogenetically most closely related to the new species and it has similar morphological characters. Ophiocordyceps tricentri was initially described as Cordyceps tricentri from Japan. It is characterised by stipitate stroma with a yellow fusoid fertile head (Yasuda 1922, Table 1). The host of C. tricentri was initially identified as Tricentrus sp. (Hemiptera, Membracidae), but later corrected to Aphrophora intermedia (Hemiptera, Aphrophoridae) (Yasuda 1922). Later, Aphrophora flavomaculata, Aphrophora rugosa and Peuceptyelus medius were reported as the hosts of C. tricentri (Kobayasi 1941, Shrestha 2017). Additionally, another species, Cordyceps aphrophorae, was synonymised with C. tricentri (Yasuda 1922, Lim and Kim 1973). Shrestha and Sung 2005) recorded Cordyceps tricentri obtained from Nepal, but presented no molecular data (Table 1). Following molecular phylogenetic analyses, $C$. tricentri was transferred to Ophiocordyceps (Sung et al. 2007b). Ban et al. 2015) presented sequence data of $O$. tricentri from strain NBRC 106968, but did not provide morphological information. It is clear that more data are needed to fully understand the species limits with regards to $O$. tricentri. The new species, $O$. aphrophoridarum, is morphologically similar to $O$. tricentri, but can be recognised by its longer and finer stromata and much longer asci (Yasuda 1922, Shrestha and Sung 2005, Table 1).

Table 1.

Synopsis of closely-related Ophiocordyceps species. Measurements in $\mu \mathrm{m}$.

\begin{tabular}{|l|l|l|l|}
\hline Species & O. aphrophoridarum & O. tricentri (holotype) & $\begin{array}{l}\text { O. tricentri (EFCC } \\
7251,7252)\end{array}$ \\
\hline Distribution & China & Japan & Nepal \\
\hline Stromata $\mathbf{( m m )}$ & $\begin{array}{l}\text { Clavated, branched or unbranched, 80- } \\
100 \times 0.5-1.2\end{array}$ & Fusoid, yellow, unbranched & $\begin{array}{l}\text { Solitary, yellow, 50-60 } \\
\times 1-1.5\end{array}$ \\
\hline
\end{tabular}




\begin{tabular}{|c|c|c|c|}
\hline $\begin{array}{l}\text { Fertile heads } \\
(\mathrm{mm})\end{array}$ & Yellow single, allantoideus, $10-20 \times 2-5$ & & Ovoid, $50-60 \times 1-1.5$ \\
\hline Perithecia $(\mu \mathrm{m})$ & $\begin{array}{l}\text { Obliquely buried, ovoid to elongated } \\
\text { pyriform, } 638-798 \times 108-178\end{array}$ & & $\begin{array}{l}\text { Immersed, ovoid, 550- } \\
650 \times 110-120\end{array}$ \\
\hline Asci $(\mu \mathrm{m})$ & $\begin{array}{l}\text { 8-spored, hyaline, filiform, } 337-445 \times \\
6.1-8.7\end{array}$ & Cylindrical, $120 \times 5-6$ & $300-320 \times 5$ \\
\hline $\begin{array}{l}\text { Partspores } \\
(\mu \mathrm{m})\end{array}$ & $\begin{array}{l}\text { Fusoid, 1-celled, straight, hyaline, 6.4- } \\
8.8 \times 1.4-2.4\end{array}$ & $\begin{array}{l}\text { Fusoid, smooth, } 1 \text {-celled, } \\
\text { hyaline, } 8-10 \times 1.5\end{array}$ & \\
\hline References & This study & Yasuda 1922 & $\begin{array}{l}\text { Shrestha and Sung } \\
2005\end{array}$ \\
\hline
\end{tabular}

In conclusion, there is sufficient evidence from both morphology and molecular phylogenetic analyses to support $O$. aphrophoridarum as a new species of Ophiocordyceps.

\section{Acknowledgements}

This work was supported by the Biodiversity Survey and Assessment Project of the Ministry of Ecology and Environment of China (2019HJ2096001006) and the Science and Technology Foundation of Guizhou Province (Nos. [2019]2451-3 \& [2019]2333).

\section{References}

- $\quad$ Araujo JPM, Evans HC, Mackay WP, Geiser DM, Hughes DP (2015) Unravelling the diversity behind the Ophiocordyceps unilateralis (Ophiocordycipitaceae) complex: Three new species of zombie-ant fungi from the Brazilian Amazon. Phytotaxa 220 (3): 224-238. https://doi.org/10.11646/phytotaxa.220.3.2

- $\quad$ Araujo JPM, Evans HC, Kepler R, Hughes DP (2018) Zombie-ant fungi across continents: 15 new species and new combinations within Ophiocordyceps. I. Myrmecophilous hirsutelloid species. Studies in Mycology 90: 119-160. https://doi.org/ 10.1016/j.simyco.2017.12.002

- $\quad$ Araujo JPM, Hughes DP (2019) Zombie-ant fungi emerged from non-manipulating, beetle-infecting ancestors. Current Biology 29 (21): 3735-3738. https://doi.org/10.1016/ j.cub.2019.09.004

- $\quad$ Araujo JPM, Evans HC, Fernandes IO, Ishler MJ, Hughes DP (2020) Zombie-ant fungi cross continents: II. Myrmecophilous hymenostilboid species and a novel zombie lineage. Mycologia 112 (6): 1138-1170. https://doi.org/10.1080/00275514.2020.1822093

- Ban S, Sakane T, Nakagiri A (2015) Three new species of Ophiocordyceps and overview of anamorph types in the genus and the family Ophiocordycipitaceae. Mycological Progress 14 (1): 1-12. https://doi.org/10.1007/s11557-014-1017-8

- Capella-Gutiérrez S, Silla-Martínez J, Gabaldón T (2009) trimAl: a tool for automated alignment trimming in large-scale phylogenetic analyses. Bioinformatics 25 (15):

1972-1973. https://doi.org/10.1093/bioinformatics/btp348 
- Castlebury L, Rossman A, Sung G, Hyten A, Spatafora J (2004) Multigene phylogeny reveals new lineage for Stachybotrys chartarum, the indoor air fungus. Mycological Research 108 (8): 864-872. https://doi.org/10.1017/S0953756204000607

- $\quad$ Cheek M, Lughadha EN, Kirk PM, Lindon H, Niskanen T (2020) New scientific discoveries: Plants and fungi. Plants People Planet 2 (5): 371-388.

- Crous P, Luangsa-Ard J, Wingfield MJ, Carnegie A, Hernández-Restrepo M, Lombard L, Roux J, Barreto R, Baseia I, Cano J, Martín M, Morozova O, Stchigel AM, Summerell B, Brandrud TE, Dima B, García D, Giraldo López A, Guarro J, Groenewald JZ (2018) Fungal Planet description sheets- 785 - 867. Persoonia - Molecular Phylogeny and Evolution of Fungi $41 \mathrm{https}$ ://doi.org/10.3767/persoonia.2018.41.12

- De Bekker C, Quevillon L, Smith P, Fleming K, Ghosh D, Patterson A, Hughes D (2014) Species-specific ant brain manipulation by a specialized fungal parasite. BMC Evolutionary Biology 14 https://doi.org/10.1186/PREACCEPT-8313271611363357

- $\quad$ Evans H, Elliot S, Hughes D (2011) Hidden diversity behind the zombie-ant fungus Ophiocordyceps unilateralis: Four new species described from carpenter ants in Minas Gerais, Brazil. PLOS One 6 https://doi.org/10.1371/journal.pone.0017024

- Hall T, Biosciences I, Carlsbad C (2011) BioEdit: An important software for molecular biology. GERF Bull. Biosci. 2: 60-61.

- Hoang DT, Chernomor O, von Haeseler A, Minh BQ, Vinh LS (2018) UFBoot2: Improving the Ultrafast Bootstrap Approximation. Molecular Biology and Evolution 35 (2): 518-522. https://doi.org/10.1093/molbev/msx281

- Hopple J, Vilgalys R (1994) Phylogenetic relationships among coprinoid taxa and allies based on data from restriction site mapping of nuclear rDNA. Mycologia 86: 96-107. https://doi.org/10.1080/00275514.1994.12026378

- Hywel-Jones N (1995) Cordyceps sphecocephala and a Hymenostilbe sp. infecting wasps and bees in Thailand. Mycological Research 99 (2): 154-158. https://doi.org/ 10.1016/S0953-7562(09)80879-4

- Hywel-Jones N (1996) Cordyceps myrmecophila-like fungi infecting ants in the leaf litter of tropical forest in Thailand. Mycological Research 100 (5): 613-619. https://doi.org/ 10.1016/S0953-7562(96)80017-7

- Johnson D, Sung GH, Hywel-Jones NL, Luangsa-Ard JJ, Bischoff JF, Kepler RM, Spatafora JW (2009) Systematics and evolution of the genus Torrubiella (Hypocreales, Ascomycota). Mycological Research 113 (3): 279-289. https://doi.org/10.1016/j.mycres. 2008.09.008

- Kalyaanamoorthy S, Minh BQ, Wong T, Haeseler AV, Jermiin LS (2017) ModelFinder: Fast Model Selection for Accurate Phylogenetic Estimates. Nature Methods 14 (6). https://doi.org/10.1038/nmeth.4285

- $\quad$ Katoh K, Standley D (2013) MAFFT multiple sequence alignment software version 7: improvements in performance and usability. Molecular Biology and Evolution 30: 772-780. https://doi.org/10.1093/molbev/mst010

- $\quad$ Kepler R, Sung GH, Ban S, Nakagiri A, Chen MJ, Huang B, Li Zz, Spatafora J (2012) New teleomorph combinations in the entomopathogenic genus Metacordyceps. Mycologia 104: 182-197. https://doi.org/10.3852/11-070

- Kepler R, Ban S, Nakagiri A, Bischoff J, Hywel-Jones N, Owensby C, Spatafora J (2013) The phylogenetic placement of hypocrealean insect pathogens in the genus Polycephalomyces: An application of one fungus one name. Fungal Biology 117: 611-622. https://doi.org/10.1016/j.funbio.2013.06.002 
- $\quad$ Kepler RM, Sung GH, Ban S, Nakagiri A, Chen MJ, Huang B, Li Z, Spatafora JW (2012) New teleomorph combinations in the entomopathogenic genus Metacordyceps.

Mycologia 104 (1): 182-197. https://doi.org/10.3852/11-070

- Kobayasi Y (1941) The genus Cordyceps and its allies. Report of the Tokyo Bunrika Daigaku Section B 5 (84): 53-260.

- $\quad$ Kobayasi Y, Shimizu D (1983) Iconography of vegetable wasps and plant worms. Hoikusha Publishing Co Ltd, Osaka, 280 pp.

- Kobmoo N, Mongkolsamrit S, Arnamnart N, Luangsa-ard JJ, Giraud T (2019) Population genomics revealed cryptic species within host-specific zombie-ant fungi ( Ophiocordyceps unilateralis). Molecular Phylogenetics and Evolution 140 https://doi.org/ 10.1016/j.ympev.2019.106580

- $\quad$ Lim JH, Kim BK (1973) Taxonomic Investigations on Korean Higher Fungi(II) -Two Unrecorded Species of the Genus Cordyceps in Korea. The Korean Journal of Mycology 1 (1): 13-16.

- $\quad$ Long FY, Qin LW, Xiao YP, Hyde K, Wang SX, Wen TC (2021) Multigene phylogeny and morphology reveal a new species, Ophiocordyceps vespulae, from Jilin Province, China. Phytotaxa 478: 33-48. https://doi.org/10.11646/phytotaxa.478.1.2

- $\quad$ Luangsa-Ard J, Tasanathai K, Thanakitpipattana D, Khonsanit A, Stadler M (2018) Novel and interesting Ophiocordyceps spp. (Ophiocordycipitaceae, Hypocreales) with superficial perithecia from Thailand. Studies in Mycology 89 https://doi.org/10.1016/ j.simyco.2018.02.001

- Luo GT, Wang JX, Wen TC (2013) Resource investigation of macrofungi in Yuntai Mountain in Shibing County, Guizhou Province. Guizhou Science 31 (4).

- Maharachchikumbura S, Hyde K, Jones E, McKenzie E, Huang SK, Abdel-Wahab M, Daranagama D, Dayarathne M, D'souza M, Goonasekara I, Hongsanan S, Jayawardena R, Kirk P, Konta S, Liu JK, Liu ZY, Norphanphoun C, Pang KL, Perera R, $\mathrm{Xu} J$ (2015) Towards a natural classification and backbone tree for Sordariomycetes. Fungal Diversity 72: 199-301. https://doi.org/10.1007/s13225-015-0331-z

- Maharachchikumbura S, Hyde K, Jones E, McKenzie E, Bhat DJ, Dayarathne M, Huang SK, Norphanphoun C, Senanayake I, Perera R, Shang QJ, Xiao YP, D'souza M, Hongsanan S, Jayawardena R, Daranagama D, Konta S, Goonasekara I, Zhuang WY, Wijayawardene N (2016) Families of Sordariomycetes. Fungal Diversity 79: 1-317. https://doi.org/10.1007/s13225-016-0369-6

- Minh BQ, Schmidt HA, Chernomor O, Schrempf D, Woodhams M, Von Haeseler A, Lanfear R (2020) IQ-TREE 2: New Models and Efficient Methods for Phylogenetic Inference in the Genomic Era. Molecular Biology and Evolution (5). https://doi.org/ 10.1093/molbev/msaa015

- Mueller GM, Schmit JP (2007) Fungal biodiversity: what do we know? What can we predict? Biodiversity and Conservation 16 https://doi.org/10.1007/s10531-006-9117-7

- Petch T (1931) Notes on entomogenous fungi. Transactions of the British Mycological Society 16 (1): 55-75. https://doi.org/10.1016/S0007-1536(31)80006-3

- $\quad$ Petch T (1933) Notes on entomogenous fungi. Transactions of the British Mycological Society 18 (1): 48-75. https://doi.org/10.1016/S0007-1536(33)80026-X

- Petch T (1937) Notes on entomogenous fungi. Transactions of the British Mycological Society 21 (1): 34-67. https://doi.org/10.1016/S0007-1536(37)80005-4 
- $\quad$ Rambaut A, Drummond AJ, Xie D, Baele G, Suchard MA (2018) Posterior summarization in Bayesian phylogenetics using Tracer 1.7. Systematic Biology 67 (5): 901-904. https://doi.org/10.1093/sysbio/syy032

- $\quad$ Ronquist F, Teslenko M, Mark P, Ayres D, Darling A, Höhna S, Larget B, Liu L, Suchard $M$, Huelsenbeck J (2012) MrBayes 3.2: Efficient Bayesian phylogenetic inference and model choice across a large model space. Systematic Biology 61: 539-542.

https://doi.org/10.1093/sysbio/sys029

- Sanjuan TI, Franco-Molano AE, Kepler RM, Spatafora JW, Tabima J, Vasco-Palacios AM, Restrepo S (2015) Five new species of entomopathogenic fungi from the Amazon and evolution of neotropical Ophiocordyceps. Fungal Biology 119 (10): 901-916.

- Schoch CL, Seifert KA, Huhndorf S, Robert V, Spouge JL, Levesque CA, Chen W, Fungal Barcoding C, Fungal Barcoding Consortium Author L (2012) Nuclear ribosomal internal transcribed spacer (ITS) region as a universal DNA barcode marker for fungi. Proceedings of the National Academy of Science 109 (16): 6241-6246. https://doi.org/ 10.1073/pnas.1117018109

- Shrestha B, Sung JM (2005) Notes on Cordyceps species collected from the central region of Nepal. Mycobiology 33 (4): 235-239. https://doi.org/10.4489/MYCO. 2005.33.4.235

- Shrestha B (2017) Mycosphere Essay 19. Cordyceps species parasitizing hymenopteran and hemipteran insects. Mycosphere 8 (9): 1424-1442. https://doi.org/ 10.5943/mycosphere/8/9/8

- $\quad$ Sung GH, Sung JM, Hywel-Jones N, Spatafora J (2007a) A multi-gene phylogeny of Clavicipitaceae (Ascomycota, Fungi): Identification of localized incongruence using a combinational bootstrap approach. Molecular Phylogenetics and Evolution 44:

1204-1223. https://doi.org/10.1016/j.ympev.2007.03.011

- Sung GH, Hywel-Jones NL, Sung JM, Luangsa-ard JJ, Shrestha B, Spatafora JW (2007b) Phylogenetic classification of Cordyceps and the clavicipitaceous fungi. Studies in Mycology 57 https://doi.org/10.1016/S0166-0616(14)60128-7

- Tasanathai K, Thanakitpipattana D, Himaman W, Phommavong K, Dengkhhamounh N, Luangsa-ard J (2020) Three new Ophiocordyceps species in the Ophiocordyceps pseudoacicularis species complex on Lepidoptera larvae in Southeast Asia. Mycological Progress 19 (10): 1043-1056. https://doi.org/10.1007/s11557-020-01611-6

- Thanakitpipattana D, Tasanathai K, Mongkolsamrit S, Khonsanit A, Lamlertthon S, Luangsa-Ard JJ (2020) Fungal pathogens occurring on Orthopterida in Thailand. Persoonia - Molecular Phylogeny and Evolution of Fungi 44: 140-160. https://doi.org/ 10.3767/persoonia.2020.44.06

- Tzean SS, Hsieh LS, Wu WJ (1997) Atlas of entomopathogenic fungi from Taiwan. Council of Agriculture, Executive Yuan, Taiwan.

- Vilgalys R, Hester M (1990) Rapid genetic identification and mapping of enzymatically amplified ribosomal DNA from several Cryptococcus species. Journal of Bacteriology 172 (8): 4238-4246. https://doi.org/10.1128/jb.172.8.4238-4246.1990

- Wen TC, Zha LS, Xiao YP, Wang Q, Kang JC, Hyde K (2015) Metacordyceps shibinensis sp. nov. from larvae of Lepidoptera in Guizhou Province, Southwest China. Phytotaxa 226 https://doi.org/10.11646/phytotaxa.226.1.5

- Wen TC, Xiao YP, Han Yf, Huang SK, Zha LS, Hyde K, Kang JC (2017) Multigene phylogeny and morphology reveal that the Chinese medicinal mushroom 'Cordyceps 
gunnii' is Metacordyceps neogunnii sp. nov. Phytotaxa 302 https://doi.org/10.11646/ phytotaxa.302.1.2

- White TJ, Bruns T, Lee S, Taylor J (1990) Amplification and direct sequencing of fungal ribosomal RNA genes for phylogenetics: PCR-protocols and applications-A laboratory manual. In: Innis M, Gelfand D, Sninsky J, White T (Eds) PCR Protocols. Academic Press, San Diego, 315-322 pp. [ISBN 978-0-12-372180-8]. https://doi.org/10.1016/ B978-0-12-372180-8.50042-1

- Wijayawardene N, Hyde K, Rajeshkumar KC, Hawksworth D, Madrid H, Kirk P, Braun U, Singh R, Crous P, Kukwa M, Lücking R, Kurtzman C, Yurkov A, Haelewaters D, Aptroot A, Lumbsch T, Timdal E, Ertz D, Etayo J, Karunarathna S (2017) Notes for genera: Ascomycota. Fungal Diversity 86: 1-594. https://doi.org/10.1007/s13225$\underline{\text { 017-0386-0 }}$

- $\quad$ Xiao YP, Hongsanan S, Hyde K, Brooks S, Xie N, Long FY, Wen TC (2019) Two new entomopathogenic species of Ophiocordyceps in Thailand. MycoKeys 47: 53-74. https://doi.org/10.3897/mycokeys.47.29898

- $\quad$ Yasuda (1922) The botanical magazine = Shokubutsugaku zasshi. v.36 (1922). Tokyo Botanical Society, Tokyo :. URL: https://www.biodiversitylibrary.org/item/130630 [ISBN 0006-808X]

\section{Supplementary materials}

\section{Suppl. material 1: Sources of isolates and GenBank accession numbers doi}

Authors: Yu Yang, Yuan-pin Xiao, Gang-jiang Yu, Juan Meng, Zheng-hua Lu, Chun-ying Deng, Ting-chi Wen

Data type: MS Word

Brief description: Sources of isolates and GenBank accession numbers used in this study Download file $(63.56 \mathrm{~kb})$

\section{Suppl. material 2: References for GenBank accession numbers doi}

Authors: Yu Yang

Data type: MS Word

Brief description: References for GenBank accession numbers used in this study

Download file $(25.67 \mathrm{~kb})$ 